\title{
Methodological Framework for the Analysis of Brand Identity Construction
}

\author{
Gyöngyvér Erika TÖKÉS \\ Department of Applied Social Sciences \\ Faculty of Technical and Human Sciences \\ Sapientia Hungarian University of Transylvania \\ E-mail: gyongyvert@gmail.com
}

\begin{abstract}
The purpose of this study is to develop a methodological framework for examining brand identity construction. In the first part of the study, the theoretical background and conceptualization of brand identity is introduced. This section contains a comparative analysis of the most used conceptual brand identity models, which highlight key elements of the composition of brand identity in an identity-based branding approach. The second part of the study proposes the operationalization of brand identity. The third part of the study presents the operationalization schemes developed to analyze the construction of the service- and employer brand identities of software and IT companies from Cluj-Napoca. The operationalization examples are based on the content analysis of the websites of 110 software and IT companies from Cluj-Napoca. The examination was conducted in September 2018.
\end{abstract}

Keywords: Methodological framework; Conceptualization; Operationalization; Brand identity; Service brand; Employer brand. 


\section{Introduction}

The study of brand identity construction is a timely topic. One of the strategic tools of corporate differentiation in the growing economic competition is the creation of strong brands. Under the conditions of globalization of the service sector in the knowledge economy, successful brand management offers companies operating in knowledge-based sectors a significant competitive advantage.

There are many conceptual models in the brand management literature for defining and constructing brand identity, yet there is a lack of testing conceptual models and developing methodological frameworks that can be used as verified models for analyzing brand identity.

There are two approaches to develop brand identity in traditional brand management: the market-oriented outside-in approach and the identity-based insideout approach (Urde et al., 2013; Burmann et al., 2017). The goal of the marketoriented brand management is to positively influence the brand image. In the identity-based approach, the emphasis is on the corporate resources and competencies integrated in the brand identity. Focusing on the concept of brand identity is part of the resource-based approach. According to this view, brand builders rely on the internal resources and competencies of the company to build brand identity and then, by offering these, they influence customer expectations (Alsem, Kostelijk, 2008, 911).

The traditional brand management approach interprets identity development as a management-led process, considering brand identity static and stable which unifies the core attributes of the brand. The contemporary stakeholder-oriented dynamic perspective on brand management perceives brand identity formation as a continuous negotiation process of meaning development (Essamri, McKechnie, Winklhofer, 2018). According to this view brand identity is dynamic and socially constructed through networked interactions between the company and a multitude of stakeholders (da Silveira, Lages, Simões, 2013; Iglesias et al., 2019; Essamri, McKechnie, Winklhofer, 2018; von Wallpach, Hemetsberger, Espersen, 2017).

The traditional brand management approach is still valid on the point that the initial definition of brand identity is a managerial creation (Urde, Greyser, 2016, 97; Kennedy, Guzman, 2016, 314; Nandan, 2005, 268). In the increasingly complex market environments the brand identity once formulated becomes the subject of negotiation in the brand ecosystem. Trough networked interactions between the company and stakeholders a negotiated brand identity develops and gains legitimacy as a result of co-creation processes (Essamri, McKechnie, Winklhofer, 2018). The purpose of the company is to co-ordinate and "garner moral and cultural acceptance of what the brand stands for" (Essamri, McKechnie, Winklhofer, 2018).

The aim of the present study is to develop a methodological framework that can be used as a guide for analyzing brand identity construction by applying an iden- 
tity-based brand management approach (Grønhaug, Ghauri, 2016). The study also aims to demonstrate the applicability of the developed methodological framework by illustrating two operationalization examples. The first part of the study sheds light on the role of brand identity in the brand management process, clarifies the concept and constitution of brand identity, introduces the most used conceptual models of brand identity, and finally highlights the key elements in the composition of brand identity in an identity-based brand management approach. In the second part of the study, using the perspective of identity-based brand management, an operationalization scheme to explore brand identity is introduced. The third part of the study presents the operationalization schemes developed to analyze the service- and employer brand identity of software and IT companies from Cluj-Napoca. The operationalization examples are based on the content analysis of the websites of 110 software and IT companies from Cluj-Napoca. The examination was conducted in September 2018. It is not the aim of the study to analyze the characteristics of creation or co-creation processes of brand identity development but the outcome of these processes, namely the construction of brand identity as a multidimensional creation.

\section{The theoretical background of brand identity}

\section{The role of brand identity in the process of brand management}

Several renowned authors have developed models for the brand management process. The models by Keller (2013) and de Chernatony (2014), characterized by a market-oriented approach, are often cited. At the same time, the brand management model by Burmann et al. (2017), that employs an identity-based approach, is also noteworthy. Based on a comparison of the above brand management models, and adopting an identity-based brand management perspective, the following common steps in the brand management process can be identified:

a. Strategic brand analysis: customer analysis, competitor analysis, self-analysis of the brand.

b. Defining brand identity: defining the essential characteristics of the brand from a strategic point of view of the company, formulating the vision and mission of the brand in internal and external terms, defining central brand values, identifying internal resources.

c. Brand positioning: identifying the position of the brand on the market among competitors, defining similarities and differences with competitors.

d. Brand targeting: delimits the target audience of the brand.

e. Grasping the essence of the brand: formulating the brand slogan and mantra

f. Design and implementation of internal branding activities: formulation of internal branding goals, development of internal marketing and communication programs. 
g. Design and implementation of external branding activities: formulation of external branding goals, development of external marketing and communication programs.

h. Measuring and evaluating internal brand performance.

i. Measuring and evaluating external brand performance.

j. Brand architecture: defining the relationship of existing brands within the company, developing brand expansion strategies.

k. Brand development: increasing brand value and adapting, modernizing.

The above steps represent a cyclic sequence, and each brand management step affects the overall process. The consistency of brand management process models is noticeable in the sense that defining brand identity is one of the initial managerial steps in brand management, the implementation of which affects the entire process (Aaker, Joachimsthaler, 2009, 13).

Until a strong brand identity develops, the process of brand identity formation undergoes several stages. Törmälä and Gyrd-Jonesa (2017) distinguish three intermediate type of brand identity, such as latent, emergent and clarified; finally, the adjusted brand identity is taking shape through different brand management (creation and co-creation) processes. In this sense, brand identity is a "co-created phenomenon that emerges from continuous dialectic processes of interaction in social contexts" (Csaba, Bengtsson, 2006).

\section{Conceptual models of brand identity}

Developing an inspiring brand identity is the basis for building a strong brand (Aaker, Joachimsthaler, 2009, 292; Iglesias et al., 2019).

Brand identity summarizes the essential attributes of the brand from a strategic point of view of the company (Aaker, Joachimsthaler, 2009, 13). Brand identity is a multidimensional structure where the elements form a unit (Aaker, 2002; Kapferer, 2008, 187; Aaker, Joachimsthaler, 2009). Brand identity requires transparency (Aaker, Joachimsthaler, 2009, 40) in order for the stakeholders involved in brand management to interpret the essence of the brand in a similar way (Kapferer, 2008, 188; Esch, 2008, 62). The characteristics of brand identity also determine the external perception of the brand (Burmann, Jost-Benz, Riley, 2009, 391).

Several authors have developed conceptual models of the constitution of brand identity, the most frequently cited being the marketing approach models by Aaker (2002), later by Aaker and Joachimsthaler (2009), and Kapferer (2008). The socioscientific brand identity model by Burmann et al. (2017), which was inspired by the results of personal identity research, deserves special mention. 
Brand Identity Planning Model by Aaker (2002),

later by Aaker and foachimsthaler (2009)

Aaker (2002) describes the characteristics of strong brand identity in the Brand Identity Planning Model. Aaker and Joachimsthaler (2009) revise Aaker's (2002) original Brand Identity Planning Model, and republish it as an identity model for leading brands. The authors consider brand identity to be the essence of the brand. According to Aaker and Joachimsthaler, brand identity is a unique set of key attributes and benefits associated with a brand that underpin brand positioning and engagement with target groups. According to the authors, the benefits can be functional, emotional, social, and self-expressive. Brand identity system also includes a relationship element. Brand goals include building relationships with target groups, the nature of which is influenced by other elements of the brand identity. Relationships with target groups can be friendly, supportive, empowering in nature, or similar to those between parents, children, etc.

Aaker $(2002,96)$, later Aaker and Joachimsthaler $(2009,43)$ list twelve dimensions of the brand identity system, which can be grouped around four dimensions. The elements of the brand identity can be derived from the characteristics of the product or service behind the brand (purpose, characteristics, quality/value, usage, users, country of origin of the brand/service), the attributes of the company that created the brand (organizational characteristics, local or global nature), personal attributes of the brand (personality, nature of relationships) or symbols representing the brand (visual appearance, brand heritage). Aaker $(2002,78)$ emphasizes that not all brand identity elements are necessarily required in the construction of brand identity, but that the primacy of any identity element jeopardizes brand balance (Aaker 2002, 68).

In the model by Aaker (2002, 96), later Aaker and Joachimsthaler $(2009,44)$, there are three levels of brand identity: (a) the essence, (b) the core identity and (c) the extended identity. The essence of brand identity is the central thought that represents the soul of the brand (Aaker, Joachimsthaler, 2009, 45). Brand essence resonates with customers while ensures that the brand is distinguished from its competitors (Aaker, Joachimsthaler, 2009, 45). Core identity is a constant part of the brand and does not change as the brand evolves. The extended part of the brand identity is dynamic, ensuring the complexity, completeness and development of the brand.

According to Aaker $(2002,87)$, the integration of the organizational characteristics of the company establishing the brand into the brand identity facilitates differentiation. When a company manifests itself in a specific way, such as showing innovative, quality-oriented or relationship-oriented behavior, it actually refers to the values and beliefs of the company that are also reflected in the brand promise. Aaker and Joachimsthaler $(2009,53)$ emphasize that the integration of corporate 
identity elements in the brand identity is typical for service providing and hightech companies, which have quite similar service offerings, but the combination of corporate identity elements is difficult to copy, thus allowing for strong separation from competitors.

According to Aaker $(2002,87)$, the core identity of the brand points out four important things: the soul, core values and beliefs of the brand, the mission of the brand creators, and the important competencies that ensure the credibility of the brand.

The adaptability of the brand is ensured by its extended brand identity elements. These include the brand personality, the differentiating role of which is emphasized by Aaker and Joachimsthaler (Aaker, 2002, 83; Aaker, Joachimsthaler, $2009,53)$. In their opinion, a brand with an interesting personality is more attractive than a brand based on functional benefits, because target groups of the brand primarily recognize or find themselves in the brand personality, and the more similarities between themselves and the brand personality, the more sympathetic the brand is. The extended brand identity also includes the brand offer, which forms the basis of the relationship between the brand and its target groups.

\section{Kapferer's Brand Identity Prism (2008)}

Another frequently cited brand identity model is Kapferer's Brand Identity Prism (2008), developed by the author for product brands. According to the author, the concept of brand identity was triggered by increased competition in the market, as the functional benefits of the products are increasingly similar, and therefore do not ensure differentiation. For brand creators, it is essential to formulate a brand vision that is based on corporate reality, while at the same time summarizes the essence, purpose and self-image of the brand. Brand identity creates a connection between the components of the brand; brand image can be seen as an interpretation and consequence of brand identity (Kapferer, 2008, 174).

According to Kapferer $(2008,175)$, brand identity is also the basis for brand positioning. In brand positioning, brand creators emphasize the distinctive features of the brand, which differentiate the brand from its competitors and make it attractive to the target audience. According to Kapferer $(2008,182)$, successful brand identity represents for the audience relevant, imaginative, characteristic and strong values.

Kapferer $(2008,187)$ illustrates brand identity in the form of a prism with six facets that indicates the connection and ordered unity of the component elements.

- The first side of the prism is a collection of physical features and attributes (physique), since a successful brand is always based on a high quality product.

- The second side of the prism is the personality of the brand, which is discovered by the target groups when they come into contact with the brand. In many cases, the personality of the brand is represented by a spokesperson personality, whether real or symbolic. 
- The third side of the prism is the culture of brand identity. The brand identity culture is a unique combination of brand values that aligns with the brand idea, and creates the persuasive power of the brand. The culture of brand identity is significantly influenced by the culture of the brand's country of origin, which results in specific value priorities. Another important source of brand identity culture is corporate culture, which limits brand value choice. The culture of brand identity is one of the most important distinguishing features of the brand.

- The personality and culture of brand identity has an impact on another side of brand identity, namely brand relationships. Brand identity relationships refer to the nature of the relationship between the brand and target groups.

- The fifth side of brand identity prism is reflection. Reflection can easily be confused with the target audience of the brand, but the two are not the same. The target group members of the brand do not yet have the characteristics of an ideal customer, but would like to become similar to this ideal type.

- The sixth side of brand identity prism is customer self-image, which is sustained by brand consumption. The customer wants to become something through the use of the brand, and to create a desirable emotional state for themselves. Customer self-image refers to the self-image that can be maintained by the customer as a result of consuming the brand (Kapferer, 2008, 187).

From among the listed elements of brand identity, physical attributes, relationships and the reflection represent external aspects of the brand, while brand personality, culture and customer self-image reflect the internal relationship of the brand to itself. The essence of brand identity is located at the middle of the prism, which represents the substance and core values of the brand.

\section{The socio-scientific brand identity model by Burmann et al. (2017)}

Burmann et al. $(2017,44)$ used the results of personal identity research to formulate the constitution of brand identity. They compared brand identity to the identity of the individual, and brand image was compared to the social perception of the individual. Burmann et al. $(2017,42)$ compare the characteristics of individuals with weak and strong identities, and deduce the most important constitutive elements of the brand identity. According to the authors $(2017,43)$, the strong personal identity and strong brand identity manifest similarly, thus those elements of personal identity were incorporated into the brand identity that facilitate the creation of strong brand identity.

Based on the factors determining the strength of brand identity, Burmann et al. $(2017,44)$ distinguish six elements of brand identity: origin, mission/vision, competencies, values, personality and offer. The socio-scientific brand identity model developed by Burmann et al. has an origin in social science, yet it is similar to the 
Table 1. Characteristics of weak and strong identities in people and brands

\begin{tabular}{|c|c|c|}
\hline \multicolumn{2}{|c|}{ Characteristics of a } & \multirow{2}{*}{$\begin{array}{c}\text { Transfer to } \\
\text { brand identities }\end{array}$} \\
\hline weak human identity & strong human identity & \\
\hline $\begin{array}{l}\text { Many supposed „specific” identity charac- } \\
\text { teristics }\end{array}$ & $\begin{array}{l}\text { Only a few distinguished identity } \\
\text { characteristics }\end{array}$ & $\begin{array}{l}\text { Brand promise } \\
\text { and brand offer }\end{array}$ \\
\hline $\begin{array}{l}\text { Risk aversion, anxious maintenance of the } \\
\text { status quo }\end{array}$ & $\begin{array}{l}\text { Role conflicts use are used actively } \\
\text { to advance one's own identity into } \\
\text { new areas (innovative spirit) }\end{array}$ & Pers \\
\hline $\begin{array}{l}\text { Adoption of values from other (external) } \\
\text { identities }\end{array}$ & Shaping of one's own values & Values \\
\hline Strong focus on the environment & Development of a clear vision & Mission and vision \\
\hline Low level of self-confidence & High level of self-confidence & Competences \\
\hline $\begin{array}{l}\text { Lack of consciousness of one's own } \\
\text { achievements (capability) }\end{array}$ & $\begin{array}{l}\text { Achievement and accomplishments } \\
\text { of the past provide motivation for } \\
\text { new projects }\end{array}$ & \\
\hline
\end{tabular}

Source: Burmann et al., 2017, 43 - Table 2.4.

Characteristics of weak and strong identities in people and brands

marketing-oriented brand identity models when defining the essential elements of brand identity. The advantage of this model is being of general nature, which can be applied well to the empirical examination of any type of brand identity.

\section{Conceptualization of brand identity \\ from the perspective of identity-based brand management}

The comparison of the conceptual models of brand identity points to a variety of ways to conceptualize brand identity. Conceptualization is the definition of concepts that are important for the research. In conceptualization, the researcher identifies the essential aspects of the phenomenon being studied, that are integrated into the meaning of the concept. At the same time, the researcher decides about the components of the phenomenon that will not be considered (Bhattacherjee, 2012, 11).

Defining basic research concepts is a requirement of the research so that everyone can interpret research results in the same way. When defining the concepts that cover the phenomena examined in the research, it is important to state whether they are one-dimensional or multidimensional structures, and the participating dimensions included in the construction of multidimensional structures also need to be specified.

The brand identity models presented above are based on the common view according to which the formulation of brand identity is among the initial steps in building a brand. There are many similarities among the models regarding the constitution of brand identity, although certain models have specific aspects in defining the brand identity structure. 
Table 2. The comparison of conceptual brand identity models

\begin{tabular}{|c|c|c|c|}
\hline $\begin{array}{c}\text { Elements } \\
\text { of brand identity }\end{array}$ & $\begin{array}{c}\text { Aaker (2002) } \\
\text { Aaker and Joachimsthaler } \\
(2009)\end{array}$ & Kapferer (2008) & $\begin{array}{l}\text { Burmann et al. } \\
\qquad(2017)\end{array}$ \\
\hline \multicolumn{4}{|c|}{ External elements - relation with the environment } \\
\hline $\begin{array}{l}\text { External (physical) } \\
\text { appearance }\end{array}$ & $\mathrm{X}$ (brand as product) & X (external appearance) & -- \\
\hline $\begin{array}{l}\text { External (non-physical) } \\
\text { manifestation }\end{array}$ & X (brand as symbol) & -- & -- \\
\hline Relationships & $\mathrm{X}$ (brand as person) & X (relationships) & -- \\
\hline Positioning & $X$ (positioning) & -- & -- \\
\hline Reflection & -- & $X$ (reflection) & -- \\
\hline Offer & $X$ (offer) & -- & $X$ (offer) \\
\hline \multicolumn{4}{|c|}{ Internal elements - corporate resources } \\
\hline Origin & $\mathrm{X}$ (brand as organisation) & -- & $X$ (origin) \\
\hline Vision and mission & $\mathrm{X}$ (brand as organisation) & -- & $\mathrm{X}$ (mission) \\
\hline Culture and values & $\mathrm{X}$ (brand as organisation) & X (culture) & $X$ (values) \\
\hline Personality & $\mathrm{X}$ (brand as person) & X (personality) & X (personality) \\
\hline Competences & X (credibility) & -- & $\mathrm{X}$ (competences) \\
\hline Self-image & -- & X (self-image) & -- \\
\hline
\end{tabular}

Source: created by the author, 2019

Table 2 shows that in the marketing-based brand identity models (Aaker, 2002; Aaker, Joachimsthaler, 2009; Kapferer, 2008), external and internal elements work together in the structure of brand identity, whereas in the identity-based socioscientific model by Burmann et al. (2017), the components of brand identity are mainly internal elements.

In the current study, identity elements based on corporate resources and competences are included as key elements of brand identity to validate the identitybased brand management approach.

According to Table 2, the key elements of brand identity are the mission and vision of brand identity, the values and culture of brand identity, and the personality of brand identity. The mission and vision of brand identity guides the creation of the brand, anticipating the ideal state that the brand wants to achieve. The way to achieve the ideal state is determined by the values and culture of brand identity, which together form the essential part of brand identity. The personality of brand identity is responsible for building relationships with target groups. The credibility of the brand identity offer is ensured by the brand competencies.

Table 2 shows that the relationship and offer of the brand identity are among the key elements of adapting to the external environment. The brand identity offer is a very important component as brand is a promise that the brand fulfills for the 
target groups through brand activities. Brand identity relationship is closely linked to the internal components of brand identity, as the nature of brand relationship depends on the core values and personality of the brand.

By comparing conceptual brand identity models, and selecting the common elements, the brand identity can be interpreted as a multidimensional structure, consisting of six dimensions in the context of identity-based brand management (Table 3), which are based on corporate resources and competencies.

Table 3. Dimensions of brand identity from the perspective of identity-based brand management

\begin{tabular}{|c|c|}
\hline $\begin{array}{l}\text { Dimensions of } \\
\text { brand identity }\end{array}$ & The definition of dimensions \\
\hline ORIGIN & $\begin{array}{l}\text { The origin of brand identity refers to the characteristics of the brand creators and the cir- } \\
\text { cumstances in which the brand was created. Brand origin has three important components: } \\
\text { country origin, industry origin and corporate origin. }\end{array}$ \\
\hline $\begin{array}{l}\text { MISSION / } \\
\text { VISION }\end{array}$ & $\begin{array}{l}\text { The mission of brand identity is to define the role of the brand, both for external and internal } \\
\text { target groups. Examining the mission allows the identification of those brand features that } \\
\text { distinguish it from its competitors. The mission also contributes to establish the originality, } \\
\text { substance and legitimacy of the brand. }\end{array}$ \\
\hline VALUES & $\begin{array}{l}\text { The core values of brand identity refer to the beliefs, principles and way of existence of the } \\
\text { brand. Core values are the emotional component of the brand, and they influence the nature } \\
\text { of the relationships with the target groups. }\end{array}$ \\
\hline PERSONALITY & $\begin{array}{l}\text { Brand identity personality traits indicate the personality attributes brand creators (managers } \\
\text { and employees) have, as well as the attributes of the target groups the brand will most likely } \\
\text { connect with. Personality is among the emotional component of the brand that determines } \\
\text { the brand's way of thinking, emotional attitudes and the nature of its manifestations. The } \\
\text { personality traits of brand identity stem from the common behavior of brand creators. }\end{array}$ \\
\hline COMPETENCES & $\begin{array}{l}\text { Brand identity competencies sustain the credibility and highlight the brand excellence, } \\
\text { namely the areas where the brand performs better than its competitors. Excellence can be } \\
\text { based on rapid adaptability to customer expectations and market changes, as well as being } \\
\text { able to attract and retain customers and employees. }\end{array}$ \\
\hline OFFER & $\begin{array}{l}\text { Brand offer combine the benefits of the brand. Brand benefits can be functional, material and } \\
\text { symbolic (emotional, social, self-expressive). The brand offer reveal the benefits of using the } \\
\text { brand for different target groups (external and internal). }\end{array}$ \\
\hline
\end{tabular}

\section{Operationalization of service and employer brand identities based on the content analysis of the websites of software and IT companies from Cluj-Napoca}

The benefit of conceptualization lies in the preparation of operationalization (Vans, 1991, 47). The transformation into empirically measurable variables of the concepts determined in the conceptualization process takes place during the process of operationalization (Bhattacherjee, 2012, 44; Neumann, 2006, 184).

In the following, two operationalization examples are presented which, based on the presented conceptualization of brand identity, operationalize service- and employer brand identities. 
Service brand and employer brand are specific brand types that appeal to the customers, as well as employees.

- Service brand is a concept that incorporates the functional and symbolic benefits offered by the brand creators to the customers using the service, whether they are present customers or potential ones.

- Employer brand is a concept about the company's role as an employer. This concept encompasses all the functional, material and symbolic benefits that the company offers its employees, whether they are already employed or future employees.

The examples of operationalization come from the empirical research on the service and employer brand identities of software and IT companies from Cluj-Napoca. ${ }^{1}$ The research sample consisted of the websites of 110 software and IT companies from Cluj-Napoca. The method of data collection was combined content analysis. The empirical data collection was conducted in September 2018.

The text corpus analyzed by content analysis was the thematic web content published on the websites of the 110 software and IT companies from Cluj-Napoca. Only textual web content was included in the sample, up to two hierarchical levels. Thematic content on the origins, mission, vision, values and culture, the services and career opportunities of the companies were recorded from the corporate websites making up the sample, in one Word document per company. The unit of content analysis was the Word document of the company, which summarized the content recorded from the website.

The coding categories were developed in two steps. As a first step, quality content analysis was performed on 10 percent of the sample, that resulted in an inductive coding category system. As a second step, the content analysis criteria system was determined in a deductive way based on the literature. As a third step, the two coding category systems were merged. The validity of the content analysis aspects was tested by conducting a pilot research. During the pilot research, 13 websites of software and IT companies from Cluj-Napoca were coded. The pilot research highlighted redundant coding categories that were eliminated in the main research. The coding of the text corpus was assisted by the Atlas.ti quality data analysis program.

The reliability of the content analysis was tested by the Krippendorff Alpha reliability test. The analysis was performed on 10 percent of the sample. In the case of the eleven company websites selected from the 110 corporate websites examined using a simple random sampling method (using the random number generation

1 Details on the research: Tőkés Gyöngyvér Erika (2019). Online branding - Online branding strategies in the software and IT industry. The service providing and employer brand identity of software and IT companies from Cluj-Napoca based on corporate data published on their websites (doctoral thesis). Cluj-Napoca: Babeș-Bolyai University. 
function of the Excel spreadsheet program), an independent coder re-applied the developed coding category system. The value of the Krippendorff Alpha was 0.7672 , which exceeded the minimum value of 0.67 and is statistically acceptable (De Swert, 2012; Hayes, Krippendorff, 2007). The value of the correlation between the coding of the two encoders was 0.771 . This value is very close to the 0.80 correlation coefficient, which can be considered statistically good.

The following operationalization schemes contain empirical indicators that were found to be relevant to the content analysis of the service- and employer brand identities of software and IT companies from Cluj-Napoca (Vans, 1991, 52). ${ }^{2}$ Tables 4 and 5 show the itemization of the dimensions into variables and their measures. Service- and employer brand identities are made up of the same dimensions, but the variables and measures of the dimensions differ according to the roles, functions and target groups of the brands.

The operationalization schemes presented in Tables 4 and 5 establish a link between the theoretical knowledge of brand identity, conceptual models, and the reality of brand identities created by software and IT companies (Vans, 1991, 18). The operationalization schemes in Tables 4 and 5 are based on the dimensions of brand identity conceptualized in an identity-based approach, and are broken down into variables that refer to things that are observable in reality. The above tables also contain the operational definition of the variables.

During the content analysis of the websites of software and IT companies from Cluj-Napoca, the validity of the developed variables was tested, as there were several indicators in the original operationalization schemes based on the content analysis categories, which were not substantiated by the examined content. The two operationalization schemes provide a guide to examine service and employer brand identities of companies operating in the software and IT sectors. The application of the schemes facilitates the exploration of the general characteristics and differentiating attributes of service and employer brand identities.

The operationalization schemes presented are based on content analysis, but can serve as a basis for any structured data collection method.

It would be useful to compare and validate the presented operationalization schemes with other empirical models, but there is a lack of empirical testing of brand identity's conceptual models applied for different economic sectors, especially to the software and IT sector (Muhonen, Hirvonen, Laukkanen, 2017; Coleman, de Chernatony, Christodoulides, 2015; Ojasalo, Natti, Olkkonen, 2012; Kim, Hyun, 2011; Baumgarth, 2010; Spence, Essoussi, 2010).

2 Coding categories with a prevalence of more than 30 percent were considered relevant. 


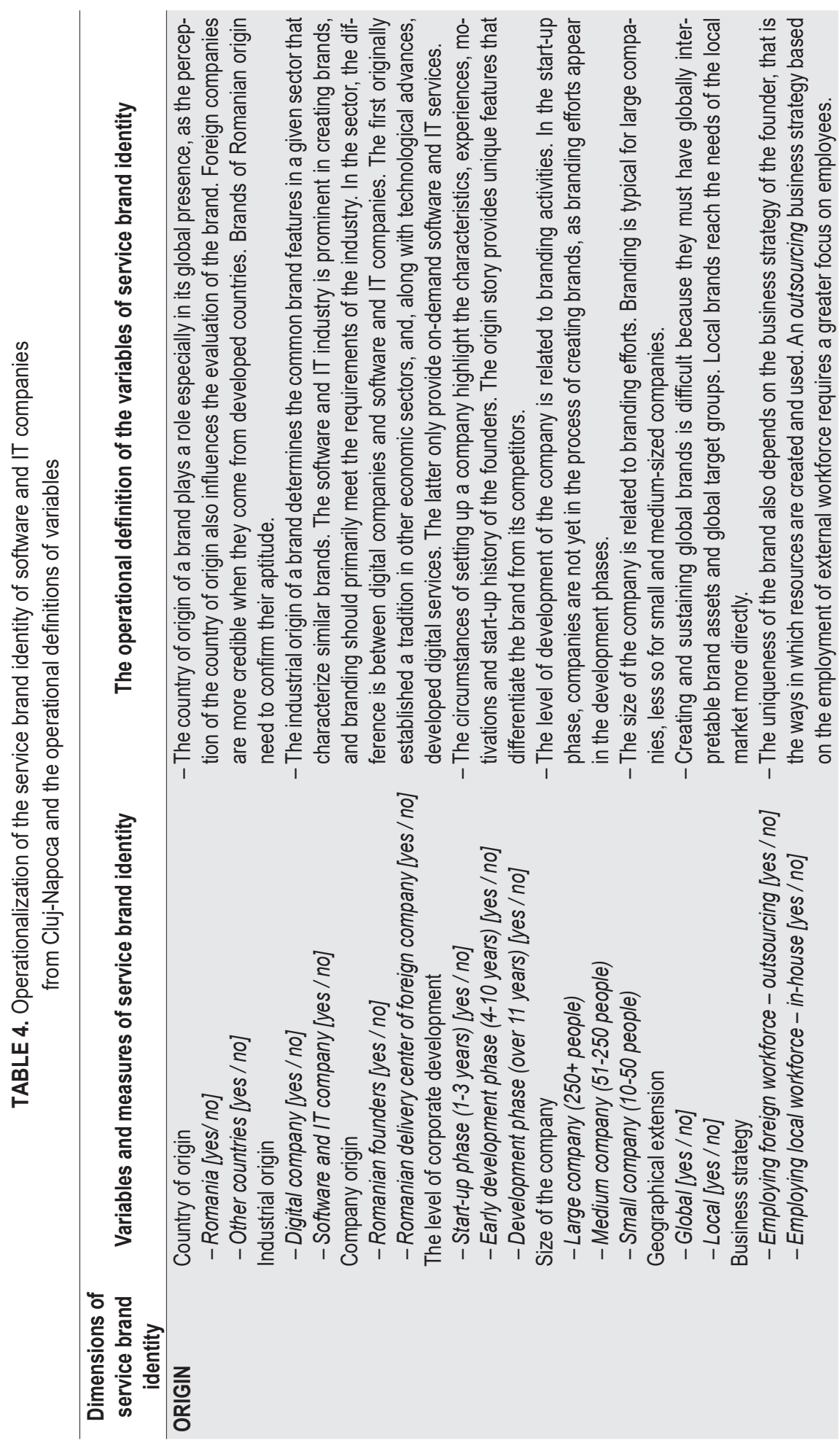



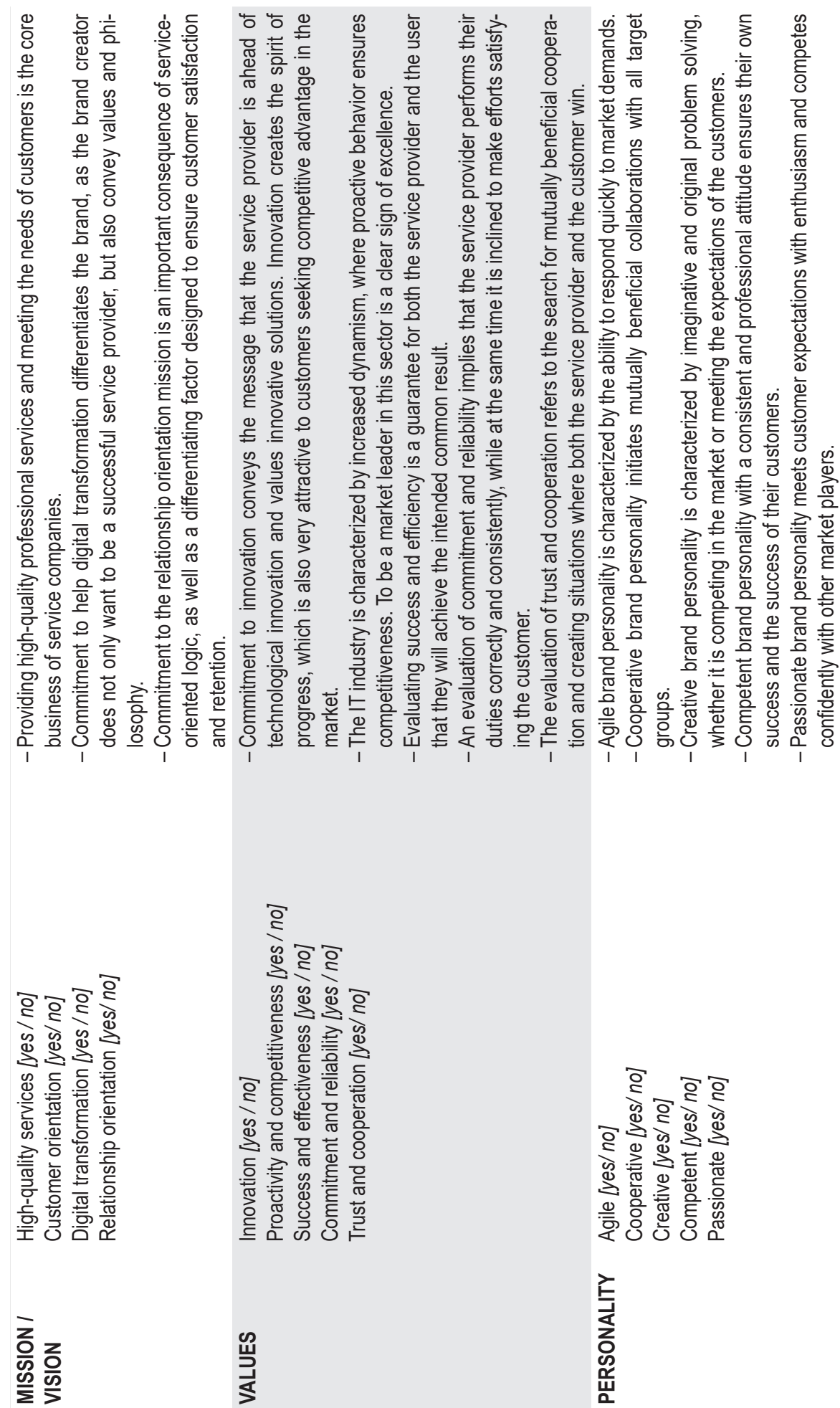

岂

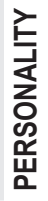




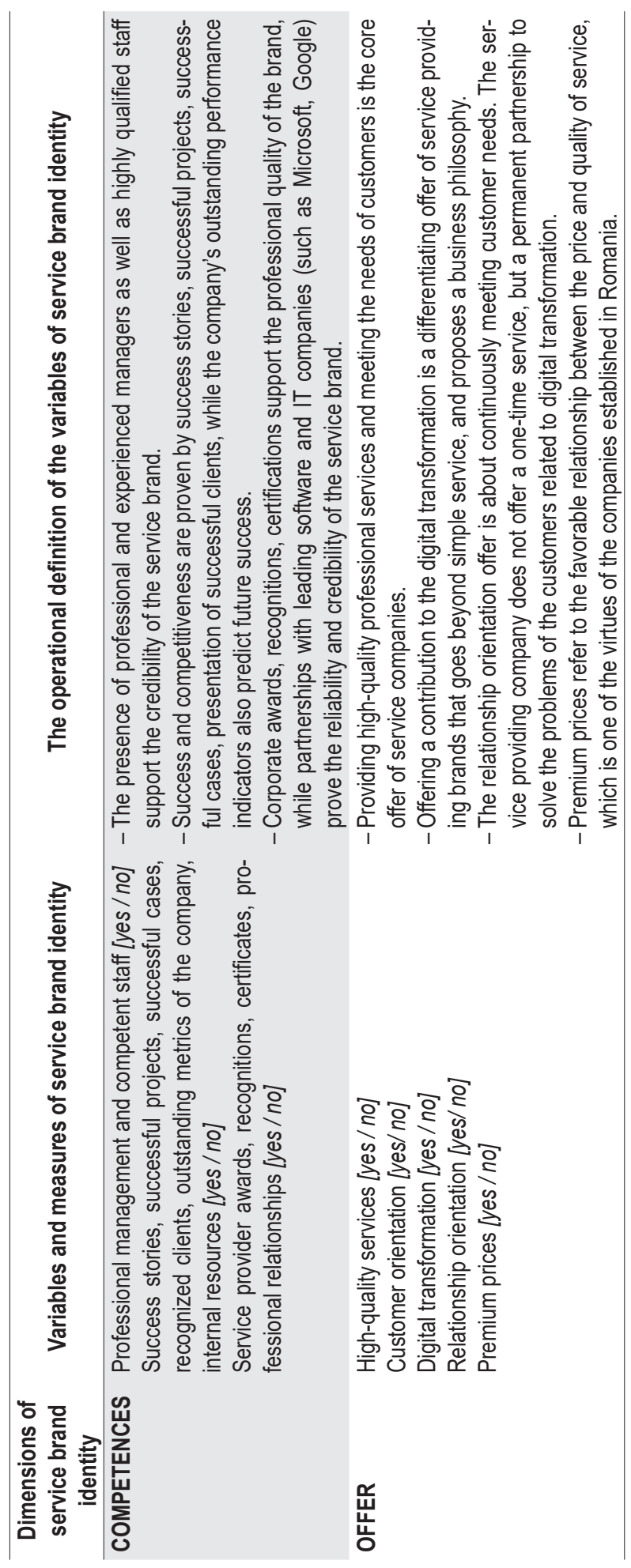




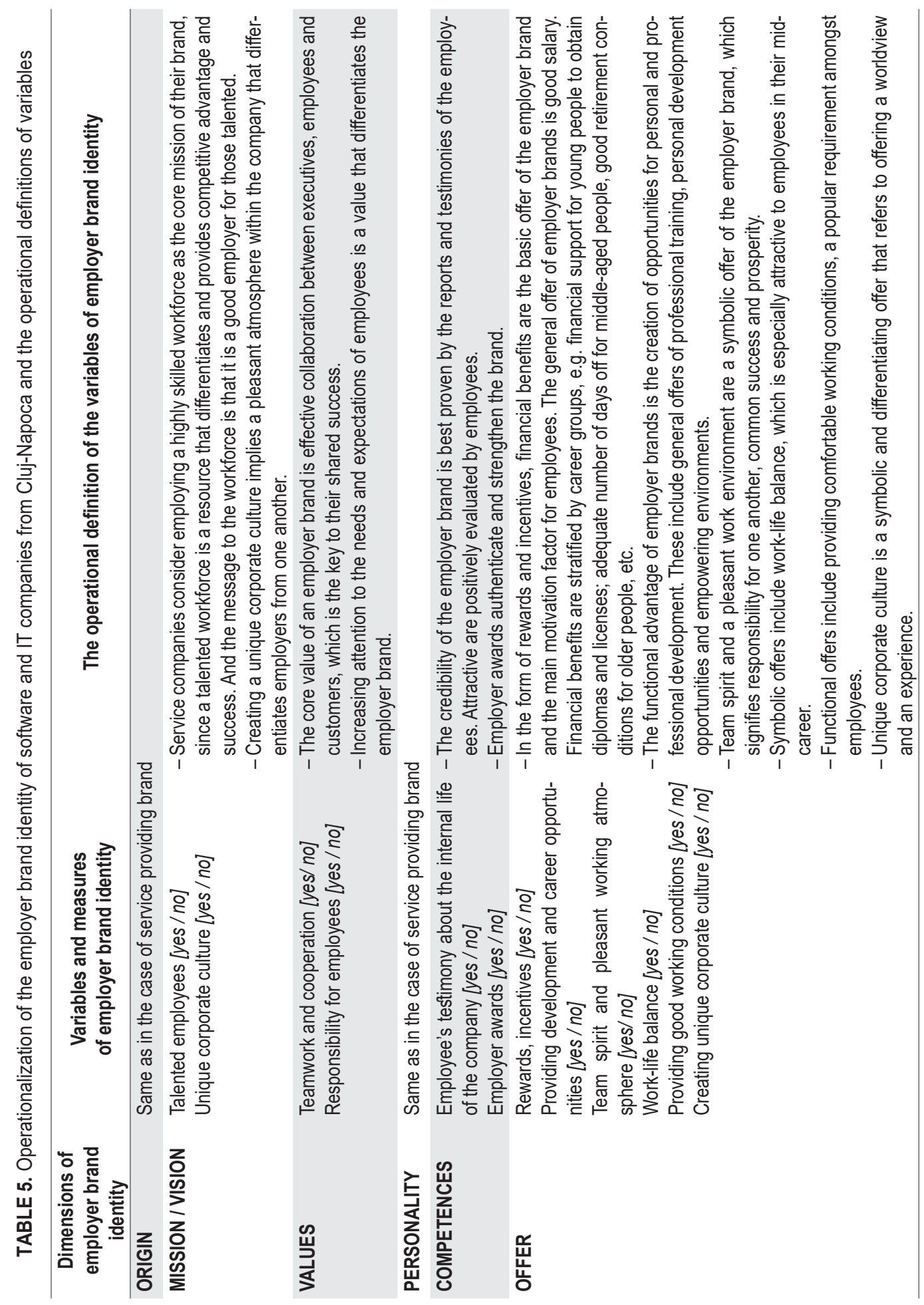




\section{Conclusion}

The aim of the study was to develop a methodological framework that can be used as a guide for examining brand identity construction by applying an identitybased brand management approach. In a knowledge-based economy, the differentiation of companies creates a competitive advantage in both the service and labor markets. An excellent tool for differentiation is brand management, the first step of which is the managerial creation of the brand identity. The methodological framework of brand identity construction can be useful for carrying out brand analysis, whether it aims to assess the position of the brand or to prepare it for further development.

In order to design a methodological framework for brand identity construction, a summary of the theoretical background presented in the first part of the study was required. In the first part of the study, the role of brand identity in the brand management process was identified, and a comparative analysis of the most used conceptual brand identity models was completed. The comparison of the brand identity models highlighted the key elements of the brand identity constitution that served as a starting point for brand identity operationalization. Brand identity was defined as a multi-dimensional concept that consists of six components: origin, vision/mission, values, personality, competencies and offer.

The applicability of the proposed brand identity operationalization scheme has been demonstrated by two examples. In the two examples, the service and employer brand identities of software and IT companies from Cluj-Napoca were operationalized, which aggregated the variables based on which these brand identities can be analyzed. The operationalization scheme of service and employer brand identities established a link between theoretical knowledge on brand identity construction, and observations of actual processes and phenomena.

As a possible continuation of the study, it would be interesting to review research on the empirical analysis of brand identity construction, to collect the conceptualization and operationalization schemes used in them, and to further develop the proposed methodological framework.

\section{References}

1. Aaker, D. A. (2002). Building strong brands. London-Sydney-New York-Toronto: Pocket Books.

2. Aaker, D. A., Joachimsthaler, E. (2009). Brand leadership. London-Sydney New YorkToronto: Pocket Books.

3. Alsem, K. J., Kosteijk (2008). Identity based marketing: a new balanced marketing paradigm. European fournal of Marketing, 42(9-10), 907-914.

4. Baumgarth, C. (2010). "Living the brand": brand orientation in the business-to-business sector. European fournal of Marketing, 44(5), 563-671. 
5. Bhattacherjee, A. (2012). Social Science Research: Principles, Methods, and Practices. USF Tampa Bay Open Access Textbooks Collection. Retrieved July 2019, from https://schol arcommons.usf.edu/.

6. Burmann, Ch., Jost-Benz, M., Riley, N. (2009). Toward an identity-based brand equity model. Journal of Business Research, 62(3), 390-397.

7. Burmann, Ch., Riley, N-M., Halaszovich, T., Schade, M. (2017). Identity-based brand management. Fundamentals-strategy-implementation-controlling. New York: Springer Gabler Verlag.

8. Coleman, D. A., de Chernatony, L., Christodoulides, G. (2015). B2B service brand identity and brand performance: an empirical investigation in the UK's B2B IT services sector. European fournal of Marketing, 49(7-8).

9. Coleman, D., de Chernatony, L., Christoloulides, G. (2011). B2B service brand identity: scale development and validation. Industrial Marketing Management, 40, 1063-1071.

10. Csaba, F. F., Bengtsson, A. (2006). Rethinking identity in brand management. In: Schröder, J. E., Mörling, M. (eds.). Brand culture. London: Routledge, 118-135.

11. da Silveira, C., Lages, C., Simões, C. (2013). Re-conceptualizing brand identity in a dynamic environment. Fournal of Business Research, 66(1), 28-36.

12. De Chernatony, L. (2014). From brand vision to brand evaluation. The strategic process of growing and strengthening brands. New York: Routledge.

13. De Swert, K. (2011). Calculating inter-coder reliability in media content analysis using Krippendorff's Alpha. University of Amsterdam. Retrieved December 2018, from https://www.polcomm.org/wp-content/uploads/ICR01022012.pdf.

14. Esch, F. R. (2008). Brand identity: the guiding star for successful brands. In: Schmitt, B. H., Rogers, D. L. (eds.). Handbook on Brand and Experience Management. Cheltenham: PEFC, 58-75.

15. Essamri, A., McKechnie, S., Winklhofer, H. (2018). Co-creating corporate brand identity with online brand communities: A managerial perspective. Fournal of Business Research, 96, 366-375. doi: https://doi.org/10.1016/j.jbusres.2018.07.015.

16. Grønhaug, K., Ghauri, P. (2016). Kutatásmódszertan az üzleti tanulmányokban (Research Methodology in the Business Sciences). Budapest: Akadémiai.

17. Hayes, A. F., Krippendorff, K. (2007). Answering the call for a standard reliability measure for coding data. Communication Methods and Measures, 1, 77-89.

18. Iglesias, O., Landgraf, P., Ind, N., Markovic, S., Koporcic, N. (2019). Corporate brand identity co-creation in business-to-business contexts. Industrial Marketing Management, 85, 32-43. doi: https://doi.org/10.1016/j.indmarman.2019.09.008.

19. Kapferer, J. N. (2008). The new strategic brand management. Creating and sustaining brand equity long term. London: Kogan Page.

20. Keller, K. L. (2013). Strategic brand mangement. Building, measuring, and managing brand equity. Boston-New York-San Francisco: Pearson.

21. Kennedy, E., Guzman, F. (2016). Co-creation of brand identities: consumer and industry influence and motivations. Journal of Consumer Marketing, 33(5), 313-323. 
22. Kim, J.-H., Hyun, Y. J. (2011). A model to investigate the influence of marketing-mix efforts and corporate image on brand equity in the IT software sector. Industrial Marketing Management, 40, 424-438.

23. Muhonen, T., Hirvonen, S., Laukkanen, T. (2017). SME Brand identity: Its components, and performance effects, Journal of Product \& Brand Management, 26(1).

24. Nandan, S. (2005). An exploration of the brand identity-brand image linkage: A communications perspective. Journal of Brand Management, 12(4), 264-278.

25. Neumann, W. L. (2006). Social research methods. Qualitative and quantitative approaches. Boston-New York-San Francisco: Pearson.

26. Törmälä, M., Gyrd-Jonesa, R. I. (2017). Development of new B2B venture corporate brand identity: A narrative performance approach. Industrial Marketing Management, 65, 76-85. doi: http://dx.doi.org/10.1016/j.indmarman.2017.05.002.

27. Urde, M. (2013). The corporate brand identity matrix. fournal of Brand Management, 20(9), 742-761.

28. Urde, M., Greyser, S. A. (2016). The corporate brand identity and reputation matrix - the case of the Nobel prize. fournal of Brand Management, 23(1), 89-117.

29. Vans, D. A. (1991). Surveys in social research. London: UCL Press.

30. Von Wallpach, S., Hemetsberger, A., Espersen, P. (2017). Performing identities: process of brand and stakeholder identity co-construction. Fournal of Business Research, 70, 443452. doi: 10.1016/j.jbusres.2016.06.021.

31. Von Wallpach, S., Voyer, B., Kastanakis, M., Mühlbacher, H. (2016). Co-creating stakeholder and brand identties: introduction to the special edition. Fournal of Business Research. doi: 10.1016/j.jbusres.2016.08.028.

32. Spence, M., Essoussi, L. H. (2010). SME brand building and management: an exploratory study. European fournal of Marketing, 44(7), 1037-1054.

33. Ojasalo, J., Natti, S., Olkkonen, R. (2012). Challenges of brand building in software SMEs. Empirical findings. International fournal of Arts \& Sciences, 5(1): 463-477. 